\title{
Type and amount of organic amendments affect enhanced biogenic methane production from coal and microbial community structure
}

\section{Authors: Katherine J. Davis, Shipeng Lu, Elliott P. Barnhart, Albert E. Parker, Matthew W. Fields, \& Robin Gerlach}

NOTICE: this is the author's version of a work that was accepted for publication in Fuel. Changes resulting from the publishing process, such as peer review, editing, corrections, structural formatting, and other quality control mechanisms may not be reflected in this document. Changes may have been made to this work since it was submitted for publication. A definitive version was subsequently published in Fuel, [Vol. 211, January 2018] DOI\#10.1016/ j.fuel.2017.09.074

Davis, Katherine J., Shipeng Lu, Elliott P. Barnhart, Albert E. Parker, Matthew W. Fields, and Robin Gerlach. "Type and Amount of Organic Amendments Affect Enhanced Biogenic Methane Production from Coal and Microbial Community Structure." Fuel 211 (January 2018): 600-608. 


\title{
Type and amount of organic amendments affect enhanced biogenic methane production from coal and microbial community structure
}

\author{
Katherine J. Davis, Shipeng Lu, Elliott P. Barnhart, Albert E. Parker, Matthew \\ W. Fields, Robin Gerlach
}

\begin{abstract}
Slow rates of coal-to-methane conversion limit biogenic methane production from coalbeds. This study de-monstrates that rates of coal-to-methane conversion can be increased by the addition of small amounts of organic amendments. Algae, cyanobacteria, yeast cells, and granulated yeast extract were tested at two concentrations $(0.1$ and $0.5 \mathrm{~g} / \mathrm{L})$, and similar increases in total methane produced and methane production rates were observed for all amendments at a given concentration. In $0.1 \mathrm{~g} / \mathrm{L}$ amended systems, the amount of carbon converted to methane minus the amount produced in coal only systems exceeded the amount of carbon added in the form of amendment, suggesting enhanced coal-to-methane conversion through amendment addition. The amount of methane produced in the $0.5 \mathrm{~g} / \mathrm{L}$ amended systems did not exceed the amount of carbon added. While the archaeal communities did not vary significantly, the bacterial populations appeared to be strongly influenced by the presence of coal when $0.1 \mathrm{~g} / \mathrm{L}$ of amendment was added; at an amendment concentration of $0.5 \mathrm{~g} / \mathrm{L}$ the bacterial community composition appeared to be affected most strongly by the amendment type. Overall, the results suggest that small amounts of amendment are not only sufficient but possibly advantageous if faster in situ coal-to-methane production is to be promoted.
\end{abstract}

Coalbed methane (CBM) is an unconventional natural gas resource formed in subsurface coal seams by thermogenic and biogenic pro-cesses. In 2015, the United States had 12,520 billion cubic feet of proven CBM reserves, and CBM production provided approximately 4\%of the total annual natural gas requirement [1,2]. The coal beds of the Powder River Basin (PRB) in southeastern Montana and northeastern Wyoming accounted for $16.3 \%$ of the CBM produced in the U.S. in 2015 [1,2], and the PRB CBM has been shown to be primarily or completely of biogenic origin [3-5].

Biogenic CBM is the result of coal-to-methane conversion by a diverse, natural microbial community [3,6-8]. Methanogenic archaea produce biogenic methane through a limited number of pathways utilizing simple substrates $\left(\mathrm{H}_{2} / \mathrm{CO}_{2}\right.$, acetate, and methyl-compounds). However, generation of these simple substrates from coal requires a diverse microbial consortium, containing both archaeal and bacterial members, with interactive metabolic strategies for sequential

fermentative processes to degrade coal to simpler fermentation by-products [3,6,7]. Biogenic methane is produced continuously in active coal basins, and methods have been proposed for increasing the rate and volume of microbially-produced methane [9].

Rates of commercial biogenic gas removal often exceed the rates of microbial production, resulting in reduced gas extraction. Thus, gas production from many wells is no longer economically viable [10], especially with decreased prices for natural gas due to increases in shale gas production in the 2000s. This has increased the cost-to-profit ratio for CBM retrieval, and many wells have been abandoned. The existing infrastructure creates an ideal opportunity for microbially-enhanced CBM (MeCBM) methods to increase coal-to-methane conversion rates and CBM volume thus extending the lifespan of current and future wells.

Ritter et al. summarized laboratory and in situ commercial appli-cations of MeCBM techniques using various amendment methods [9]. While some studies have shown the potential for increased biogenic methane production with coal pre-treatment for enhanced 
bioavailability [11-13], significant potential exists for MeCBM strategies that stimulate microbial populations through nutrient addition $[3,9,14,15]$. Some previous CBM stimulation studies have used simple carbon substrates, such as acetate [8] or formate [16] to enhance methane production. While adding simple carbon substrates alone does increase methane production, it is unclear whether these additions enhance the coal-to-methane conversion or merely supply a more easily metabolized substrate for bacteria and/or methanogens. Inorganic limiting nutrients for biogenic coal-to-methane conversion include nitrogen, phosphorus, trace elements, and/or vitamins, and addition of these inorganic nutrients resulted in increased biogenic methane production in coal microcosms $[14,17]$. Determination of the specific nutrients needed for each potential in situ application could be costly and time-consuming.

A review of microbial life under extreme energy limitations suggested that microbial communities in subsurface environments can meet organic and inorganic nutritional requirements through biomass turnover [18]. Using this principle, it can be assumed that additions of complex nutrient sources (such as biomass) to the coal environment could provide the combination of nutrients necessary to encourage microbial growth and enhance coal degradation without the need for determining the exact amounts of specific nutrients required. Previous studies have supplemented limiting nutrients and successfully enhanced CBM production through the addition of yeast extract in conjunction with other organic or inorganic nutrient additions $[9,14,19,20]$. Barnhart et al. introduced the use of yeast and algal extracts as sole amendments to stimulate biogenic methanogenesis from coal and demonstrated a production increase with both amendments [21]. Biostimulation with yeast extract or other biomass-derived nutrient sources could provide the limiting nutrients needed for both the bacterial and archaeal populations. This could result in increased coal-to-methane conversion with potentially reduced cost and without the need to determine the exact nutrient additions needed for in situ CBM stimulation.

The goals of this study were as follows: (1) assess the potential of using four different biologically produced multi-nutrient amendments (algae, cyanobacteria, yeast cells, and granulated yeast extract) to enhance methane production from coal, (2) track carbon inputs and outputs to determine whether amendments are indeed stimulating coalto-methane conversion or merely providing an alternative carbon source for methane production, and (3) determine whether amendment addition causes significant shifts in the microbial community involved in coal-dependent methanogenesis.

\section{Materials and methods}

\subsection{Site and sample collection}

The sampling site, located near Birney (Montana, USA) in the Powder River Basin, was thoroughly described by Barnhart et al. [22]. Water from the subbituminous Flowers-Goodale (FG) coalbed was pumped and retrieved in July 2014 from the FG-11 well. Six-gallon plastic storage jugs were rinsed twice with formation water before being filled and stored at $4{ }^{\circ} \mathrm{C}$ upon return to the laboratory (Montana State University, Bozeman, MT) until microcosm set up. Coal cores were collected during the July 2013 drilling of FG monitoring wells (FGM13, FGP-13). The 2-inch diameter cores were cut into approximately 12 inch long sections and placed in polyvinyl chloride (PVC) tubes. These tubes were completely filled with formation water pumped from the FG-11 well, and sealed with flexible rubber caps to allow room for gas desorption. A detailed description of the FG coal bed samples was given by Barnhart et al. [22]. Microbial cultures were collected from two FG wells (FGM-13 and FGP-13) in November 2014 using the diffusive microbial samplers (DMS) described by Barnhart et al. [8]. The slurry (formation water with high suspended solids) from the FGP-13 DMS (13 mL) and FGM-13 DMS ( $7 \mathrm{~mL}$ ) were added to a serum bottle prepared with $5 \mathrm{~g}$ FG coal and $45 \mathrm{~mL}$ anoxic FG formation water before being allowed to incubate at room temperature in the dark for 5 months prior to being used to inoculate the studies described here.

\subsection{Amendment growth and analysis}

The microalga, Chlorella sp. strain, SLA-04 (isolated from Soap Lake, WA, USA), was cultured for biomass accumulation at $20^{\circ} \mathrm{C}$ in Bold's Basal Medium [23] in tube photobioreactors using methods previously described [24]. Anabaena cylindrica strain UTEX 1611, a nitrogen-fixing cyanobacterium, was cultured using methods similar to SLA-04 cultivation using Blue-Green Medium (BG-11) [25] without the nitrogen source. For both SLA-04 and UTEX 1611, daily cell counts were used to determine stationary phase when the cell counts were highest, $6.0 \times 10^{7}$ and $4.0 \times 10^{7}$ cells $/ \mathrm{mL}$ respectively. A yeast, Saccharomyces cerevisiae strain EtOH-Red, was cultured in $100 \mathrm{~mL}$ of Yeast Extract Peptone Dextrose (YPD) medium [26] in $250 \mathrm{~mL}$ flasks at $37{ }^{\circ} \mathrm{C}$ and shaken at $100 \mathrm{rpm}$ to keep cells in suspension. Optical density (OD) at $600 \mathrm{~nm}$ was measured daily. Yeast culture $(5 \mathrm{~mL})$ was collected in $26 \mathrm{~mL}$ Balch tubes, and OD was measured with Unico 1100RS tube spectrophotometer (Dayton, NJ, USA). OD increased from an initial OD of $0.77-1.97$ OD at stationary phase. The biomass from all three cultures was concentrated by centrifugation, dried by lyophilization, and stored at $-20{ }^{\circ} \mathrm{C}$. SLA-04, UTEX 1611, and EtOH-Red biomass as well as granulated yeast extract (EMD Millipore Corporation) (known hereafter as algae, cyanobacteria, yeast, and YE, respectively) were sent to the Iowa State University Soil and Plant Analysis Laboratory (Ames, Iowa) for elemental analysis (Supplementary Table S1) [27].

\subsection{Microcosm set up}

All microcosms were set up anoxically in $26 \mathrm{~mL}$ Balch tubes with butyl rubber stoppers and aluminum crimp seals (Supplementary Fig. S1). The FG coal core (depth 374-375') was opened in an anaerobic glove bag where it was dried, crushed, and sieved to an effective size range of $0.85-1.19 \mathrm{~mm}$. The prepared coal was stored in oxygen-free glass bottles until microcosm set up. Borosilicate glass beads (GB) (1 mm diameter) were autoclaved for controls and used in lieu of coal to provide a carbon-free solid substrate. Each Balch tube received $1 \mathrm{~g}$ of prepared coal or GB. The formation water was sparged for $5 \mathrm{~h}$ with anoxic nitrogen gas and reduced with sulfide (1 mM as $\mathrm{Na}_{2} \mathrm{~S} \cdot 9 \mathrm{H}_{2} \mathrm{O}$ ). Resazurin $(1 \mathrm{mg} / \mathrm{L})$ was used as a visual redox indicator. The amendments (algae, cyanobacteria, yeast, and YE) were ground to a fine powder with a ceramic mortar and pestle. Two concentrations of each amendment were prepared at $10 \times$ desired concentration $(0.1$ and $0.5 \mathrm{~g} / \mathrm{L}$ final concentration) in degassed FG formation water and sealed anaerobically in serum bottles. All amended treatments received $1 \mathrm{~mL}$ of this prepared amendment concentrate as appropriate. The headspace of all tubes was replaced with $5 \% \mathrm{CO}_{2}, 95 \% \mathrm{~N}_{2}$. $\mathrm{pH}$ was tested to ensure a range of 7.5-8.5 as observed in the FG formation water [22] and adjusted with $1 \mathrm{M} \mathrm{HCl}$ as necessary. All inoculated treatments received $1 \mathrm{~mL}$ of the inoculum described above; $3 \mathrm{~mL}$ of the inoculum slurry was stored at $-80{ }^{\circ} \mathrm{C}$ for microbial community analysis. All microcosms were incubated at room temperature $\left(21 \pm 1{ }^{\circ} \mathrm{C}\right)$ in the dark for 111 days, and headspace gas was sampled and analyzed approximately every 2 weeks.

\subsection{Gas analysis}

Methane production was monitored using an SRI Instruments (Torrance, CA, USA) Model 8601C GC equipped with a thermal conductivity detector (TCD) and interfaced with PeakSimple Chromatography software. A Supelco Molecular Sieve 13X packed stainless steel column ( 6 feet $\times 1 / 8^{\prime \prime}$ O.D.) was used with ultra-high purity helium carrier gas for separation using the following conditions: manual injection, oven temperature $40{ }^{\circ} \mathrm{C}$, TCD temperature $150{ }^{\circ} \mathrm{C}$, and carrier gas pressure $18 \mathrm{psi}$. Gas samples $(1 \mathrm{~mL})$ were taken from the 
Table 1

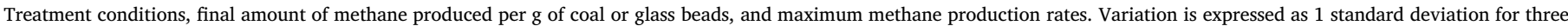
replicates of each treatment.

\begin{tabular}{|c|c|c|c|c|c|}
\hline Treatment & $\begin{array}{l}\text { Solid Substrate } \\
(1 \mathrm{~g})\end{array}$ & Amendment & $\begin{array}{l}\text { Amendment concentration } \\
(\mathrm{g} / \mathrm{L})\end{array}$ & $\begin{array}{l}\text { Methane produced in } 111 \text { days } \\
\text { ( } \mu \mathrm{g} \mathrm{CH} \mathrm{CH}_{4} / \mathrm{g} \text { coal or glass beads) }\end{array}$ & $\begin{array}{l}\text { Maximum methane production rate } \\
\text { ( } \mu \mathrm{g} \mathrm{CH} 4 / \mathrm{g} \text { coal or glass beads/day) }\end{array}$ \\
\hline 1 & Coal & - & 0 & $676.2 \pm 323.9$ & $16.3 \pm 13.0$ \\
\hline 2 & Glass beads & - & 0 & $0.0 \pm 0.0$ & $0.0 \pm 0.0$ \\
\hline 3 & Coal & Algae & 0.1 & $1370.8 \pm 19.4$ & $45.8 \pm 0.7$ \\
\hline 4 & Glass beads & Algae & 0.1 & $110.6 \pm 48.5$ & $2.7 \pm 1.1$ \\
\hline 5 & Coal & Cyanobacteria & 0.1 & $1390.0 \pm 17.7$ & $45.7 \pm 0.5$ \\
\hline 6 & Glass beads & Cyanobacteria & 0.1 & $169.2 \pm 12.5$ & $3.9 \pm 1.0$ \\
\hline 7 & Coal & Yeast & 0.1 & $1434.6 \pm 18.7$ & $49.5 \pm 0.9$ \\
\hline 8 & Glass beads & Yeast & 0.1 & $144.0 \pm 35.4$ & $3.8 \pm 0.6$ \\
\hline 9 & Coal & Yeast extract & 0.1 & $1456.0 \pm 53.9$ & $50.2 \pm 1.5$ \\
\hline 10 & Glass beads & Yeast extract & 0.1 & $147.4 \pm 21.0$ & $5.1 \pm 1.7$ \\
\hline 11 & Coal & Algae & 0.5 & $1959.9 \pm 33.5$ & $56.2 \pm 0.4$ \\
\hline 12 & Glass beads & Algae & 0.5 & $63.7 \pm 36.2$ & $1.6 \pm 0.3$ \\
\hline 13 & Coal & Cyanobacteria & 0.5 & $2185.4 \pm 96.7$ & $64.7 \pm 2.8$ \\
\hline 14 & Glass beads & Cyanobacteria & 0.5 & $91.0 \pm 14.5$ & $2.2 \pm 0.2$ \\
\hline 15 & Coal & Yeast & 0.5 & $2118.0 \pm 263.1$ & $61.3 \pm 1.7$ \\
\hline 16 & Glass beads & Yeast & 0.5 & $930.4 \pm 66.9$ & $18.8 \pm 13.7$ \\
\hline 17 & Coal & Yeast extract & 0.5 & $2125.0 \pm 6.1$ & $63.1 \pm 2.7$ \\
\hline 18 & Glass beads & Yeast extract & 0.5 & $608.6 \pm 237.0$ & $22.8 \pm 1.4$ \\
\hline
\end{tabular}

microcosm headspace for GC injection. To prevent creating a negative pressure in the tubes, $1 \mathrm{~mL}$ of anoxic $5 \% \mathrm{CO}_{2}$ in $\mathrm{N}_{2}$ gas was injected prior to withdrawing samples.

\subsection{DNA extraction and microbial community analysis}

On day 111, one replicate of each treatment was destructively sampled for DNA analysis. The coal or GB and liquid fractions were separated by decanting the liquid into a $15 \mathrm{~mL}$ Falcon conical centrifuge tube. The coal/GB was transferred to a separate $15 \mathrm{~mL}$ Falcon tube. One $\mathrm{mL}$ of $10 \%$ sodium dodecyl sulfate (SDS) was added to the coal/GB and the tube was placed in a $70{ }^{\circ} \mathrm{C}$ water bath for $30 \mathrm{~min}$. The liquid fraction was centrifuged and the supernatant decanted and discarded to leave approximately $2 \mathrm{~mL}$ with the pellet. Both sample fractions were stored at $-80^{\circ} \mathrm{C}$ until extraction.

The coal/SDS mixture was heated in a $70{ }^{\circ} \mathrm{C}$ water bath for an additional $30 \mathrm{~min}$ just before extraction. Total sample DNA was extracted using the FastDNA Spin Kit for Soil (MP Biomedical, Solon, OH) according to the manufacturer's instructions with minor modifications. Instead of $500 \mathrm{mg}$ of soil, $200 \mu \mathrm{L}$ of the centrifuged liquid fraction and $200 \mu \mathrm{L}$ of the pre-treated coal/SDS fraction were used. Times for homogenizing ( $60 \mathrm{~s}$ ), binding matrix (20 min), and air drying after the SEWS/ethanol wash (25 min) were extended to increase DNA recovery. After extraction, the DNA was prepared for PCR amplification using the OneStep ${ }^{\mathrm{TM}}$ PCR Inhibitor Removal Kit (Zymo Research, Irvine, CA).

Extracted DNA was quantified using a Qubit fluorometer and dsDNA HS Assay Kits (Thermo Fisher Scientific). The 16S rRNA genes were PCR-amplified for thirty cycles with DreamTaq PCR Master Mix (Thermo Fisher Scientific) and annealing temperature of $55{ }^{\circ} \mathrm{C}$ for $30 \mathrm{~s}$ using the universal prokaryotic primers Pro341F (5'-CCTAC GGGNBGCASCAG-3') and Pro805R (5'-GACTACNVGGGTATCTAATCC$3^{\prime}$ ), which amplify the V4 region of the 16S rRNA gene of bacteria and archaea [28]. Amplicons were checked by agarose gel electrophoresis with GelRed DNA stains (Biotium). Library preparation for Illumina MiSeq sequencing was carried out following Illumina's standard protocol "16S Metagenomic Sequencing Library Preparation" prior to being loaded for sequencing on the MiSeq v.3 platform. Sequence reads were analyzed using the MiSeq standard operating procedure of the Mothur software package [29]. In brief, paired reads were joined into contigs. The resulting contigs were screened for ambiguous base pairs, amplicon size, alignment positions, and chimeric sequences. The qualified unique contigs were classified with the Mothur formatted version of the Ribosomal Database Project (RDP; https://rdp.cme.msu.edu/) training sets with cutoff value of 80 . Chloroplast-, mitochondria- and eukarya-like sequences were removed from the analysis. Remaining sequences were binned into phylotypes according to taxonomic classification, and a relative abundance plot for each library was generated. Amplicon sequences from this study were uploaded to National Center for Biotechnology Information (NCBI) Sequence Read Archive (SRA) (http://www.ncbi.nlm.nih.gov/sra) under accession numbers SRR5342596 to SRR5342613.

\subsection{Statistical analyses}

Differences in microbial community composition were examined through principal component analysis of non-transformed phylotype relative abundances using the CANOCO 4.5 software package (Microcomputer Power, Ithaca, NY). A three-way ANOVA with interaction and Tukey comparisons were used to test for the effects of coal, amendment type, and concentration using the statistical software Minitab v17. A $p$-value less than 0.05 determined significance.

\section{Results}

\subsection{Effects of coal and amendments}

To assess the effects of the four amendments on coal-dependent biogenic methane production, 18 treatments, each in triplicate, were utilized (Table 1). Produced methane was detectable by day 19 for all coal treatments except for the unamended coal and the $0.1 \mathrm{~g} / \mathrm{L}$ algae and cyanobacteria amended coal treatments. By day 35, methane was detected in all coal-containing treatments, and the $0.1 \mathrm{~g} / \mathrm{L}$ algae and cyanobacteria amended coal treatments had methane production comparable to the other $0.1 \mathrm{~g} / \mathrm{L}$ coal treatments at all subsequent sampling time points (Fig. 1). Coal treatments produced significantly $(p<0.0005)$ more gas overall than the corresponding GB treatments (i.e., amendment-only glass bead controls). The $0.5 \mathrm{~g} / \mathrm{L}$ yeast and yeast extract (YE) GB treatments had detectable methane on day 19, but methane was detected later for all other GB treatments: day 63 for $0.1 \mathrm{~g} / \mathrm{L}$ amended GB treatments and day 54 for $0.5 \mathrm{~g} / \mathrm{L}$ algae and cyanobacteria amended GB treatments. The unamended GB treatment produced no detectable methane during the 111-day duration of the study (Fig. 1).

The total methane produced by the unamended coal treatments was $676 \mu \mathrm{g} \mathrm{CH}_{4} / \mathrm{g}$ coal after 111 days. For amended coal treatments with the same amendment concentration, regardless of amendment type, 

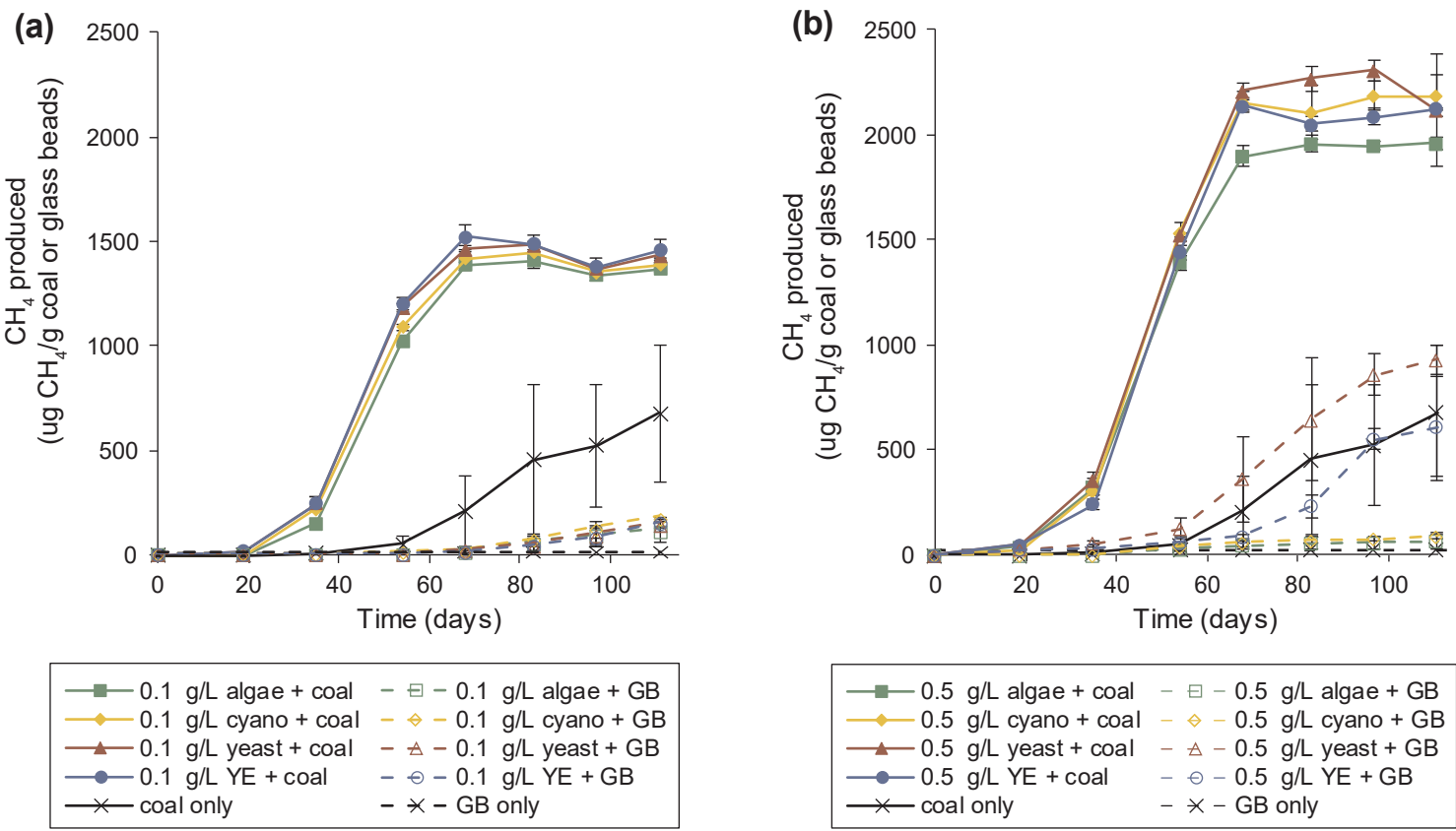

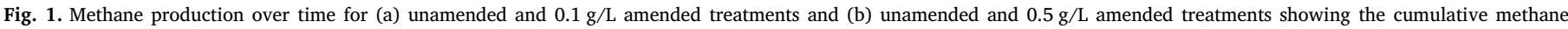

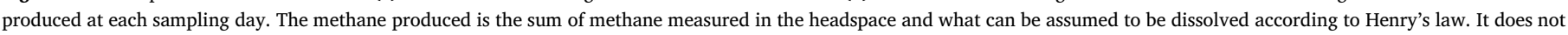
include methane that may be sorbed to the coal or glass beads. Error bars represent one standard deviation for triplicates of each treatment.

final amounts of methane produced were not significantly different for either $0.1 \mathrm{~g} / \mathrm{L}(p=1)$ or $0.5 \mathrm{~g} / \mathrm{L}(p>0.608)$ amendment concentration. The final methane concentrations for all $0.1 \mathrm{~g} / \mathrm{L}$ amended coal treatments ranged from 1371 to $1456 \mu \mathrm{g} \mathrm{CH} / \mathrm{g}$ coal whereas the $0.5 \mathrm{~g} /$ $\mathrm{L}$ amended coal treatments ranged from 1960 to $2185 \mu \mathrm{g} \mathrm{CH} / \mathrm{g}$ coal. These results indicate that all four amendments increase methane production similarly in microcosms containing coal. All four $0.1 \mathrm{~g} / \mathrm{L}$ amended GB treatments produced methane ranging from 111 to $169 \mu \mathrm{g} \mathrm{CH}_{4} / \mathrm{g}$ GB $(p=1)$. However, the $0.5 \mathrm{~g} / \mathrm{L}$ yeast and YE coalfree GB treatments began producing significantly more $(p<0.006)$ methane by day 60 than the algae and cyanobacteria amended GB treatments. Overall, the $0.5 \mathrm{~g} / \mathrm{L}$ yeast and YE GB treatments produced 930 and $609 \mu \mathrm{g} \mathrm{CH}_{4} / \mathrm{g} \mathrm{GB}$, respectively, significantly more than the $0.5 \mathrm{~g} / \mathrm{L}$ algae or cyanobacteria amended GB treatments at 64 and $91 \mu \mathrm{g} \mathrm{CH} / \mathrm{g}$ GB $(p<0.001)$. Statistically significant groupings for the total methane produced for all treatments can be found in the Supplementary Information (Table S2).

All coal treatments produced more methane than the corresponding GB treatments, suggesting coal was an important carbon source for biogenic methane production. This observation was supported by previous studies in which coal treatments produced more methane than coal-free controls $[15,21]$. The total methane production on day 111 was similar for coal treatments with equal amendment amount regardless of amendment type. However, while the increase in methane production observed in the $0.5 \mathrm{~g} / \mathrm{L}$ amended coal treatments was not statistically different between amendments, the variation between the corresponding amended GB treatments suggests that the yeast and YE amendments slightly better promote microbial activity that may be supportive of coal-to-methane conversion. This could be due to a higher bioavailability of yeast and YE in general or due to higher concentrations of macronutrients, such as phosphate (Supplementary Table S1) or micronutrients in yeast or YE amended treatments.

The average rate of methane production was calculated for each treatment for every time-period between samplings (Supplementary Table S3). Maximum production rates are shown in Table 1. The maximum rate for all amended coal treatments was observed between days 35 and 54 at $45.7-50.2 \mu \mathrm{g} \mathrm{CH}_{4} / \mathrm{g}$ coal/day for $0.1 \mathrm{~g} / \mathrm{L}$ amended treatments and $56.2-64.7 \mu \mathrm{g} \mathrm{CH}_{4} / \mathrm{g} \mathrm{coal} /$ day for $0.5 \mathrm{~g} / \mathrm{L}$ amended treatments. Statistically significant groupings of the maximum rate similarities were determined (Supplementary Table S2). The rates of methane production in $0.5 \mathrm{~g} / \mathrm{L}$ amended coal treatments regardless of amendment type were significantly different from all $0.1 \mathrm{~g} / \mathrm{L}$ amended coal and all GB treatments receiving the same amendment $(p<0.032)$. The $0.5 \mathrm{~g} / \mathrm{L}$ cyanobacteria, yeast, and YE amended treatments did not have significantly different rates of methane production $(p>0.413)$. The maximum rate of the $0.5 \mathrm{~g} / \mathrm{L}$ algae amended coal treatments was slightly lower and significantly different from the rates of the other $0.5 \mathrm{~g} / \mathrm{L}$ amended treatments $(p<0.032)$. The maximum production rates of the coal only treatments were lower at $16.3 \mu \mathrm{g} \mathrm{CH}_{4} / \mathrm{g}$ coal/day and were observed later, between days 68 and 83. The maximum methane production rate for $0.1 \mathrm{~g} / \mathrm{L}$ amended GB treatments ranged from 2.7 to $5.1 \mu \mathrm{g} \mathrm{CH} / \mathrm{g} \mathrm{GB} /$ day. Algae and cyanobacteria amended GB treatments attained maximum methane production rates during the 68-83 day time period, whereas the yeast and YE amended treatments reached maximum methane production rates during the final 97-111 day time period. Furthermore, the $0.5 \mathrm{~g} / \mathrm{L}$ amended GB treatments showed statistically significant differences in maximum methane production rates. The $0.5 \mathrm{~g} / \mathrm{L}$ algae and cyanobacteria amended GB reached maximum rates during the 35-54 day time period and ranged from 1.6 to $2.2 \mu \mathrm{g} \mathrm{CH}_{4} / \mathrm{g} \mathrm{GB} /$ day, whereas yeast and YE amended treatments were later at 68-83 and 83-97 days, respectively, and with higher rates, 18.8 and $22.8 \mu \mathrm{g} \mathrm{CH}_{4} / \mathrm{g} \mathrm{GB} /$ day. ANOVA analysis confirmed higher rates for all amended coal treatments compared to the corresponding non-coal treatments $(p<0.0005)$ regardless of amendment type or concentration. In addition, the rate achieved between days 35 and 54 for amended coal treatments was significantly higher than the rates during any other period $(p<0.0005)$. The maximum methane production rate achieved by the $0.5 \mathrm{~g} / \mathrm{L}$ amended coal treatments was statistically greater than the maximum rate achieved by the $0.1 \mathrm{~g} / \mathrm{L}$ amended coal treatments.

\subsection{Amendment concentration effect on coal-to-methane conversion}

To evaluate the effect of amendment concentration, two amendment concentrations, 0.1 and $0.5 \mathrm{~g} / \mathrm{L}$, and unamended conditions were compared. While an increase in methane production was observed with 
increasing amendment concentration for all 4 amendments (Fig. 1), the increase observed in amended coal treatments was not proportional to the amount of amendment added. The average total methane produced by the $0.5 \mathrm{~g} / \mathrm{L}$ amended coal treatments was $2097 \mu \mathrm{g} \mathrm{CH} 4 / \mathrm{g}$ coal of which approximately $1421 \mu \mathrm{g} \mathrm{CH} / \mathrm{g}$ coal was in excess of the production observed in unamended coal treatments. The average total methane produced in $0.1 \mathrm{~g} / \mathrm{L}$ amended coal treatments was $1412 \mu \mathrm{g} \mathrm{CH} /$ g coal with approximately $736 \mu \mathrm{g} \mathrm{CH}_{4} / \mathrm{g}$ coal in excess of the unamended coal treatment. The methane produced in excess of the unamended coal treatment can be attributed to the addition of amendment and includes both the methane due to enhanced coal-to-methane conversion and due to direct amendment-to-methane conversion. While the amendment concentration in the $0.5 \mathrm{~g} / \mathrm{L}$ amendment treatments was five times greater than in the $0.1 \mathrm{~g} / \mathrm{L}$ treatments, the increase in total methane production was only two times greater. Thus, it appears that increasing amendment concentration can lead to diminishing returns, and methane enhancement can be achieved while minimizing the amount of amendment needed. From this analysis, it appears that $0.1 \mathrm{~g} /$ $\mathrm{L}$ is advantageous for this purpose compared to $0.5 \mathrm{~g} / \mathrm{L}$.

\subsection{Carbon source for increased methane production in amended coal treatments}

The observed increase in methane production in amended coal treatments compared to unamended coal treatments could be attributed to the conversion of one or both of the major carbon sources present, coal or amendment. If the increased methane production is due to coal conversion, the effect of the amendment is enhancement. If the increased methane production is only due to direct conversion of the amendment to methane, the amendment's effect is only that of an alternative carbon source (feeding). The enhancement versus feeding effect of the amendments was analyzed in two ways.

First, it was observed for the duration of this study that the methane produced by amended coal treatments exceeded the sum of the methane produced by the corresponding amended GB treatments and the methane produced by the coal only treatments (Eq. (1)). The methane production of the unamended coal treatments was the 111-day methane potential of coal conversion alone while that of the amended GB treatments was the 111-day methane potential of conversion of the amendment alone. Methane produced by the corresponding amended coal treatments in excess of this sum was likely due to coal-to-methane conversion enhancement instead of amendment-to-methane conversion.

$\mathrm{CH}_{4_{(\text {amended coal })}}>\mathrm{CH}_{4_{(\text {unamended coal })}}+\mathrm{CH}_{4_{(\text {amended } G B)}}$

For example, on day 111, the sum of the methane produced by the unamended coal treatment and the $0.1 \mathrm{~g} / \mathrm{L}$ algae amended GB was $787 \mu \mathrm{g} \mathrm{CH} / \mathrm{g}$ coal or GB. The $0.1 \mathrm{~g} / \mathrm{L}$ algae amended coal treatment produced $1371 \mu \mathrm{g} \mathrm{CH} / \mathrm{g}$ coal. The $584 \mu \mathrm{g} \mathrm{CH}_{4} / \mathrm{g}$ coal or GB difference is the amount of methane produced in these treatments due to enhancement of coal-to-methane conversion.

The total methane produced for all amended coal treatments, regardless of amendment type or amount, exceeded the sum of unamended coal and corresponding amended GB treatments for all sampling dates in this study. The difference was greatest on day 68 for all treatments. Thus, the results shown here clearly indicate an increase in methane production for amended coal treatments due to enhanced coalto-methane conversion during the 111-day study.

A second analysis, based on a carbon balance, supports the hypothesis that complex organic amendments can enhance coal-to-methane conversion amounts and rates during the 111-day study. The total amount of carbon added as amendment was calculated for each treatment based on the elemental analysis of the amendments (Table 2). The total carbon moles $(\mathrm{Cmol})$ of methane produced was calculated for each coal treatment using the methane produced for each sampling point
Table 2

Carbon added as amendment calculated from elemental analysis.

\begin{tabular}{llll}
\hline \multirow{2}{*}{ Amendment } & \multicolumn{2}{l}{ Carbon added as Amendment $(\mathrm{mg})$} \\
\cline { 2 - 4 } & unamended & $0.1 \mathrm{~g} / \mathrm{L}$ amendment & $0.5 \mathrm{~g} / \mathrm{L}$ amendment \\
\hline Algae & 0 & 0.40 & 2.0 \\
Cyanobacteria & 0 & 0.47 & 2.4 \\
Yeast & 0 & 0.46 & 2.3 \\
Yeast extract & 0 & 0.48 & 2.4 \\
\hline
\end{tabular}

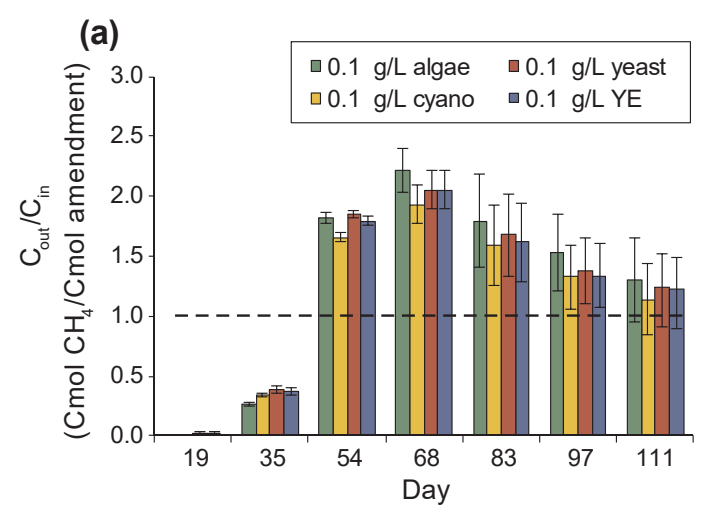

(b)

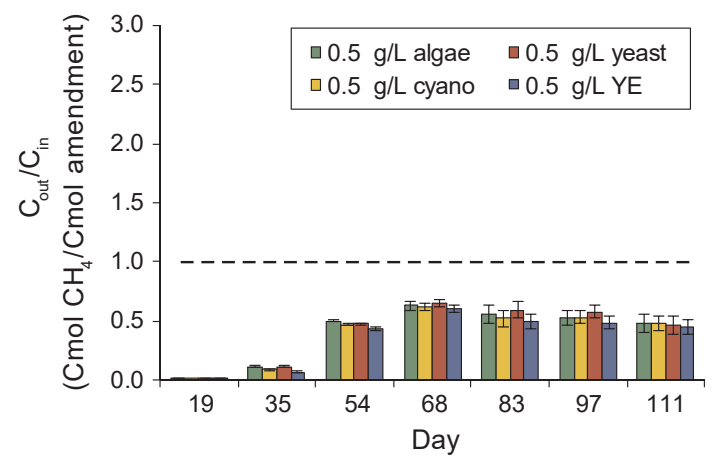

Fig. 2. Amount of carbon detected as methane relative to the amount of carbon added as amendment for (a) $0.1 \mathrm{~g} / \mathrm{L}$ amended systems and (b) $0.5 \mathrm{~g} / \mathrm{L}$ amended systems. For the $0.1 \mathrm{~g} / \mathrm{L}$ treatments, starting at 54 days, more carbon had been converted into methane than was added with the amendment, clearly indicating enhanced coal to methane conversion.

during the 111-day study (Fig. 1). Fig. 2 shows the ratio of $\mathrm{Cmol}$ of methane produced to $\mathrm{Cmol}$ of amendment added, or more simply, $\mathrm{C}_{\text {out }}$ / $\mathrm{C}_{\text {in }}$, for the $0.1 \mathrm{~g} / \mathrm{L}$ (Fig. 2a) and $0.5 \mathrm{~g} / \mathrm{L}$ (Fig. 2b) amended coal treatments as calculated by Eq. (2):

$\frac{C_{\text {out }}}{C_{\text {in }}}=\frac{\mathrm{Cmol} \mathrm{CH}_{4_{(\text {amended coal })}}-\mathrm{Cmol} \mathrm{CH}_{4_{(\text {unamended coal })}}}{\mathrm{Cmol}_{(\text {amendment })}}$

The Cmol of methane produced by the unamended coal treatment was subtracted from the $\mathrm{Cmol}$ of methane produced by the amended coal treatments at each time point so that $\mathrm{C}_{\text {out }}$ reflects only the $\mathrm{Cmol}$ of methane produced up to that time point due to amendment, either by amendment conversion (feeding) or enhanced coal-to-methane conversion (enhancement).

For the $0.1 \mathrm{~g} / \mathrm{L}$ coal treatments (Fig. $2 \mathrm{a}$ ) $\mathrm{C}_{\text {out }} / \mathrm{C}_{\text {in }}$ was greater than 1 for all amendments by day 54, demonstrating that the Cmol methane produced exceeded the $\mathrm{Cmol}$ added as amendment. Consequently, any produced methane resulting in a ratio greater than 1 is due to coal-tomethane conversion in excess of the unamended coal treatment and not just the conversion of the amendment itself to methane. Thus, it can be concluded that the increase in methane production in the presence of the $0.1 \mathrm{~g} / \mathrm{L}$ amended coal treatments was due to enhanced coal-to- 


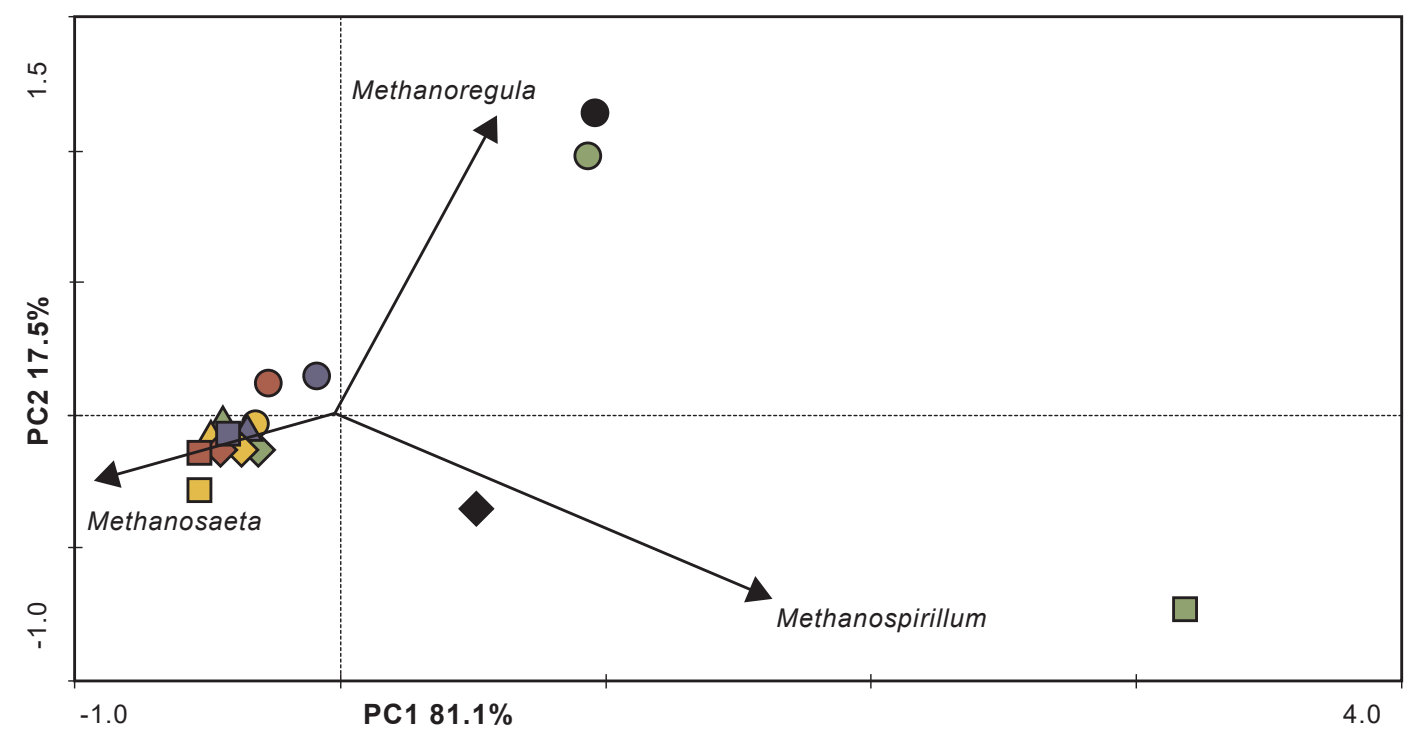

\begin{tabular}{|lll|}
\hline coal & $\diamond$ coal $+0.1 \mathrm{~g} / \mathrm{L}$ yeast & $\Delta$ coal $+0.5 \mathrm{~g} / \mathrm{L}$ cyano \\
$\diamond$ GB & $\bigcirc$ GB $+0.1 \mathrm{~g} / \mathrm{L}$ yeast & $\square \mathrm{GB}+0.5 \mathrm{~g} / \mathrm{L}$ cyano \\
$\bigcirc \mathrm{GB}+0.1 \mathrm{~g} / \mathrm{L}$ algae & $\bigcirc \mathrm{GB}+0.1 \mathrm{~g} / \mathrm{L} \mathrm{YE}$ & $\square \mathrm{GB}+0.5 \mathrm{~g} / \mathrm{L}$ yeast \\
$\diamond$ coal $+0.1 \mathrm{~g} / \mathrm{L}$ cyano & $\triangle$ coal $+0.5 \mathrm{~g} / \mathrm{L}$ algae & $\triangle$ coal $+0.5 \mathrm{~g} / \mathrm{L} \mathrm{YE}$ \\
$\bigcirc \mathrm{GB}+0.1 \mathrm{~g} / \mathrm{L}$ cyano & $\square \mathrm{GB}+0.5 \mathrm{~g} / \mathrm{L}$ algae & $\square \mathrm{GB}+0.5 \mathrm{~g} / \mathrm{L} \mathrm{YE}$ \\
\hline
\end{tabular}

Fig. 3. Principal component analysis of non-transformed relative abundances of archaeal phylotypes (at the genus level) for all treatments on day 111 .

methane conversion during the 111-day study. When similar calculations were made for the $0.5 \mathrm{~g} / \mathrm{L}$ amended coal treatments (Fig. 2b), $\mathrm{C}_{\text {out }} / \mathrm{C}_{\text {in }}$ was less than 1 for all $0.5 \mathrm{~g} / \mathrm{L}$ amended coal treatments for the duration of the study. Therefore, for all time points, the $\mathrm{Cmol}$ added as amendment exceeded the $\mathrm{Cmol}$ produced in excess of the methane produced by unamended coal treatments for all $0.5 \mathrm{~g} / \mathrm{L}$ amended coal treatments. Thus, unlike the $0.1 \mathrm{~g} / \mathrm{L}$ amended coal treatments, it cannot be asserted with certainty that the increased methane production observed in the $0.5 \mathrm{~g} / \mathrm{L}$ amended coal treatments was due to enhanced coal-to-methane conversion.

These calculations were made assuming all carbon added as amendment would have been converted to methane and none incorporated into biomass or converted to other carbon containing compounds such as $\mathrm{CO}_{2}$. Thus, it is certain that any produced methane resulting in a $\mathrm{C}_{\text {out }} / \mathrm{C}_{\text {in }}$ ratio greater than 1 was due to an enhancement of coal-to-methane conversion for that time point and not just due to the conversion of the amendment to methane. This difference between the 0.1 and $0.5 \mathrm{~g} / \mathrm{L}$ amended treatments provides additional support that the lower amendment concentration may be advantageous for coalto-methane conversion. While the production of $\mathrm{CO}_{2}$ was not analyzed in these studies, future studies utilizing this type of carbon mass balance approach would benefit from the addition of $\mathrm{CO}_{2}$ analysis resulting in a more accurate estimate of coal-to-methane conversion and reduce the underestimation effect of the assumption that all amendment carbon was converted to methane.

$\mathrm{C}_{\text {out }} / \mathrm{C}_{\text {in }}$ was similar for all amendments of the same concentration at all time points and peaked at day 68 before declining due to the continued increase in methane production by the unamended coal treatment while the methane production of the amended coal treatments leveled out. It is clear from both of these described analyses that the amendments affect coal-to-methane conversion and certainly increase the rate at which coal-to-methane conversion occurs within the duration of the 111-day study. However, it is not clear from this study what the mechanism is and whether the total amount of methane produced with amendment addition would be increased on a longer term. The greatest methane enhancement effect of the amendments during the 111-day study occurred by day 68 , and a decline was observed for later time points for all amendments and concentrations with both analyses due to the continued methane production of the unamended treatments while the amended coal methane production leveled off. To acquire preliminary data to assess this effect, one of the unamended coal treatment replicates was observed until day 322 (data not shown). The methane production continued to increase until day 229 when it leveled out and was measured at $1330 \mu \mathrm{g} \mathrm{CH} / \mathrm{g}$ coal, only slightly lower than the average 111-day methane production for the $0.1 \mathrm{~g} / \mathrm{L}$ amended coal treatments of $1412 \mu \mathrm{g} \mathrm{CH} / \mathrm{g}$ coal. While this was only one sample of the unamended coal treatment, this preliminary data suggests that both the $0.1 \mathrm{~g} / \mathrm{L}$ amended coal treatments and the unamended coal treatments might produce similar amounts of methane in batch reactors, given sufficient time. Thus, the effect of the amendment is a definite increase in the coal-to-methane conversion rate but might not result in an increase in the long-term total methane production. While it will require further investigation to test this hypothesis, an increase in the rate of coal-to-methane conversion supports the use of these amendments as a potential strategy to extract more CBM in a shorter timeframe.

\subsection{Microbial ecology differences due to the presence of coal or amendment}

Principal component analysis (PCA) was used to identify differences in microbial community composition between the 18 treatments after 111 days. The bacterial and archaeal populations were examined separately. 


\subsubsection{Archaeal population diversity}

The PCA of the archaeal communities showed little difference among the majority of the treatments except for unamended coal and GB treatments as well as algae amended GB treatments. Most treatments clustered together along the negative PC1 axis and correlated with a high relative abundance $(>0.75)$ of the genus Methanosaeta known for a preponderance of acetoclastic methanogens [30,31] (Fig. 3). A lower relative abundance of Methanosaeta was observed for the unamended coal (0.73), unamended GB (0.46), $0.1 \mathrm{~g} / \mathrm{L}$ algae amended GB (0.51), and $0.5 \mathrm{~g} / \mathrm{L}$ algae amended GB (0.17) treatments. The unamended coal treatments were still dominated by Methanosaeta but also had a higher relative abundance of the genus Methanospirillum (0.22), known for hydrogenotrophic members [32,33]. The unamended GB and the $0.1 \mathrm{~g} / \mathrm{L}$ algae GB treatments were similar: lower relative abundances of Methanosaeta than the treatments clustered along the negative PC1 axis and higher relative abundances (0.3) of Methanoregula sequences, associated with hydrogenotrophic methanogenesis pathways [34,35]. The $0.5 \mathrm{~g} / \mathrm{L}$ algae amended GB treatment was dominated by Methanospirillum (relative abundance 0.74). Overall, the PCA analysis indicates that the archaeal communities in the majority of the treatments were dominated by the genus Methanosaeta suggesting a high occurrence of acetate-to-methane conversion and that the amendment type did not significantly impact the archaeal community. The outlying treatments (unamended coal and unamended GB, 0.1 and $0.5 \mathrm{~g} / \mathrm{L}$ algae GB), however, showed greater relative abundances of the genera Methanoregula and Methanospirillum, both known to contain hydrogenotrophic members.

\subsubsection{Bacterial population diversity}

The bacterial communities for all treatments were dominated by three major phyla: Firmicutes, Proteobacteria, and Bacteroidetes. These three phyla combined to a relative abundance of $0.76-0.94$ for all treatments. Within these phyla, Clostridia and Bacilli were the dominant classes within the Firmicutes, and $\delta$-Proteobacteria and $\beta$ Proteobacteria were the dominant classes within the Proteobacteria. All of these classes have been observed previously in coal environments and contain members that are obligate anaerobic or facultative organisms and associated with syntrophic complex carbon degradation $[36,37,17]$. While all treatments showed similar bacterial composition when compared at a phylum level, greater differences between treatments were observed when analyzed at a genus level.

The bacterial phylotypes were first examined using a PCA of all 18 treatments, resulting in no discernable trends. However, when the bacterial phylotypes were examined as two separate groups: unamended plus $0.1 \mathrm{~g} / \mathrm{L}$ amended treatments (Fig. 4a) and $0.5 \mathrm{~g} / \mathrm{L}$ amended treatments (Fig. 4b), trends were observed for the two separate groups. As shown in Fig. 4a, the unamended and $0.1 \mathrm{~g} / \mathrm{L}$ amended treatments separated along the first principal component axis into coal (right) and GB (left) treatment groups. However, when examining the PCA for the $0.5 \mathrm{~g} / \mathrm{L}$ amended treatments (Fig. $4 \mathrm{~b}$ ), a similar coal and GB separation was not clearly observed. For these $0.5 \mathrm{~g} / \mathrm{L}$ amended treatments, the grouping pattern indicated an influence of amendment type instead of presence of coal with treatments loosely paired by amendment type. This observed difference in bacterial community relationships with increased amendment concentration suggests that the amendment concentration can cause shifts in the bacterial community structure and that higher amendment concentrations may have a greater influence than the presence or absence of coal. The shift could be associated with a decrease of the coal-to-methane conversion and an increase in the direct amendment to methane conversion. This is supported by the methane data indicating that higher concentrations of amendment may shift the carbon source for methane production from coal to the amendment itself.

\section{Discussion}

Yeast extract (YE), commonly added to undefined culture media as a complex nutrient source, has been investigated previously for its potential to enhance coal-to-methane conversion $[14,38,36]$. While some increase in methane production was observed in these studies, YE has costs associated with production and transport for in situ applications. This study investigated alternative complex nutrient sources and compared commercially available YE to three alternative amendments. Because all four amendments resulted in similar increases in methane production, algae, cyanobacteria, and yeast could be viable alternatives to YE for large-scale enhancement of microbial coal-to-methane conversion. Cost is always a large consideration, and each of these amendments would have varying costs associated with production, transport, and injection.

While CBM has promise as a domestic alternative to traditional coal energy, it is not without potential challenges. Because the rates of conventional CBM collection methods exceed natural rates of biogenic CBM formation, wells drilled in the PRB for CBM collection typically only have a 7-10 year lifespan [10]. During their active life, each well will produce up to 17,000 gallons of water per day, and this water must be treated before discharge or use for irrigation, resulting in thousands of holding ponds of low quality water in the PRB [39]. Barnhart et al. suggested the use of algal amendment for CBM enhancement for largescale application utilizing production water ponds to grow algae that could be used for microbial CBM enhancement while also providing valuable byproducts, such as lipids for biofuels [21]. In addition, a microalgal strain isolated from a PRB CBM production water pond has been grown in formation water with limited nutrient addition in a laboratory setting. This alga can accumulate lipids for potential biofuel production when grown in CBM formation water [40]. Many species of cyanobacteria, including the species used in this study, can fix atmospheric nitrogen, potentially further reducing necessary nutrient inputs and thus costs. Phototrophic amendments grown in CBM production water holding ponds would make use of ponds, a by-product of CBM production, and reduce transport costs by producing the amendment on or very near the site of application while utilizing sunlight and $\mathrm{CO}_{2}$ for growth.

Biogenic methane production was observed with all four amendments in the presence and absence of coal. The results presented here show that for a $0.1 \mathrm{~g} / \mathrm{L}$ amendment concentration, the additional $\mathrm{Cmol}$ methane produced is greater than the $\mathrm{Cmol}$ added as amendment, clearly demonstrating that the amount of methane produced during the 111-day study duration exceeded the carbon input from the amendment. Thus, enhanced methane production with $0.1 \mathrm{~g} / \mathrm{L}$ amendment addition is likely due to increased coal-to-methane conversion. However, while the $0.5 \mathrm{~g} / \mathrm{L}$ amended coal treatments also produced more methane than the unamended coal treatments, the additional Cmol methane produced did not exceed the $\mathrm{Cmol}$ added through the amendment. Thus, the $0.1 \mathrm{~g} / \mathrm{L}$ amendment concentration is more efficient for enhanced coal-to-methane conversion when considering the input-to-output ratio and potential costs.

While it is clear from these results that amended coal treatments produced more total methane at a higher rate than unamended coal treatments, no conclusions can be drawn regarding the longer-term effects of amendment addition on coal-to-methane conversion. It is clear that amendment addition increases the rate at which coal is converted to methane, but it appears from preliminary data that, given enough time, total methane produced from coal may be similar for both amended and unamended treatments. However, regardless of the total long-term methane production of unamended treatments, the increase in the rate of methane production with amendment addition suggests that biogenic CBM could be enhanced in the subsurface to result in the faster generation and retrieval of gases produced from coal conversion.

Bacterial community differences appeared to be influenced by the presence or absence of coal for unamended and $0.1 \mathrm{~g} / \mathrm{L}$ amended 
(a)

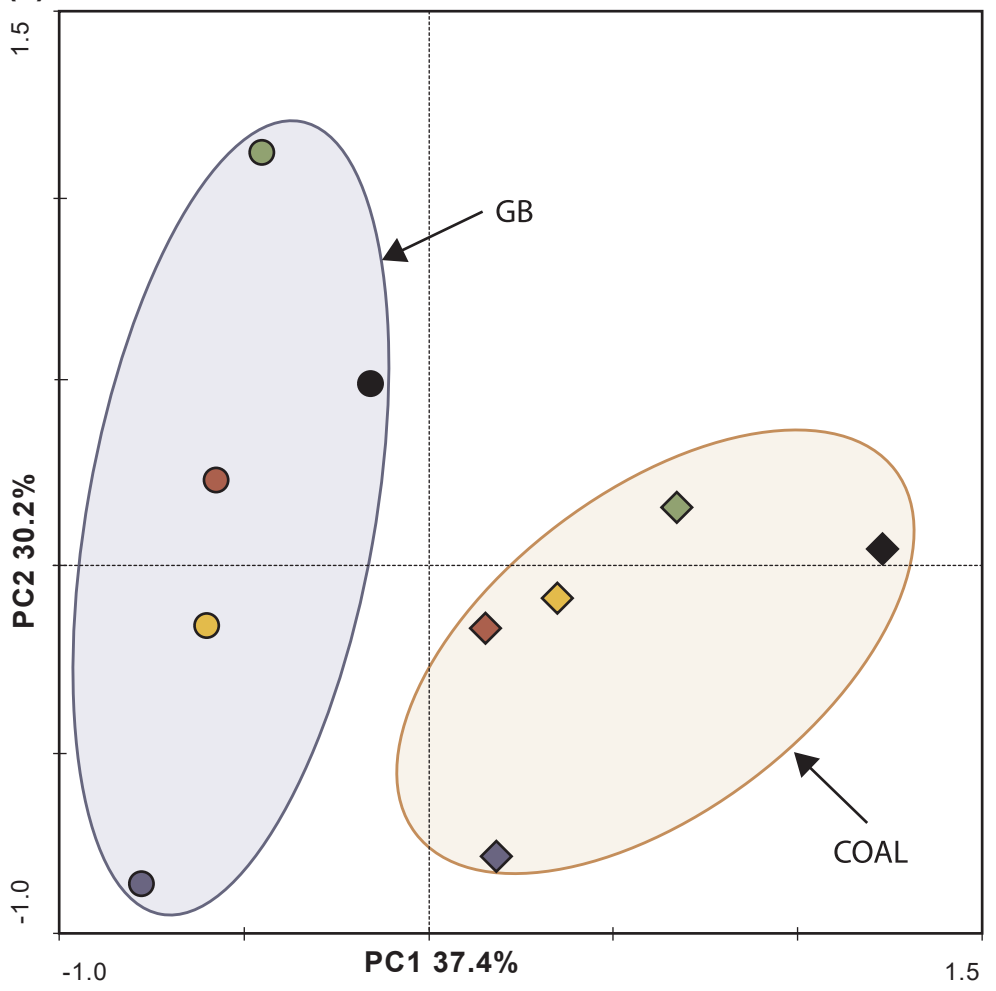

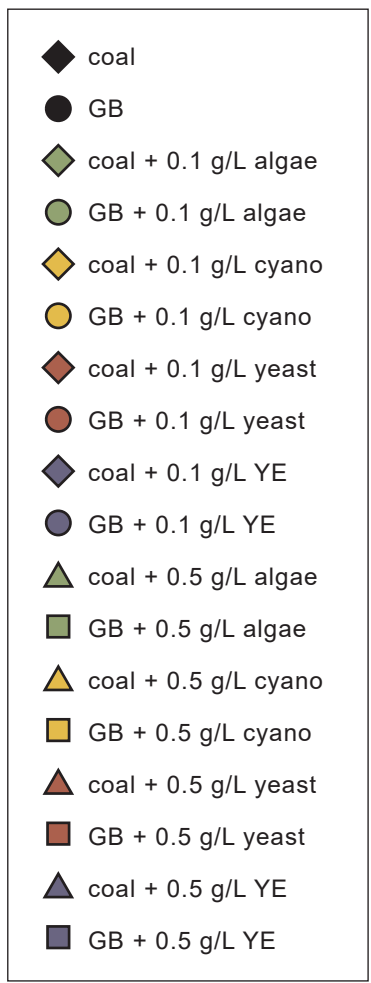

(b)

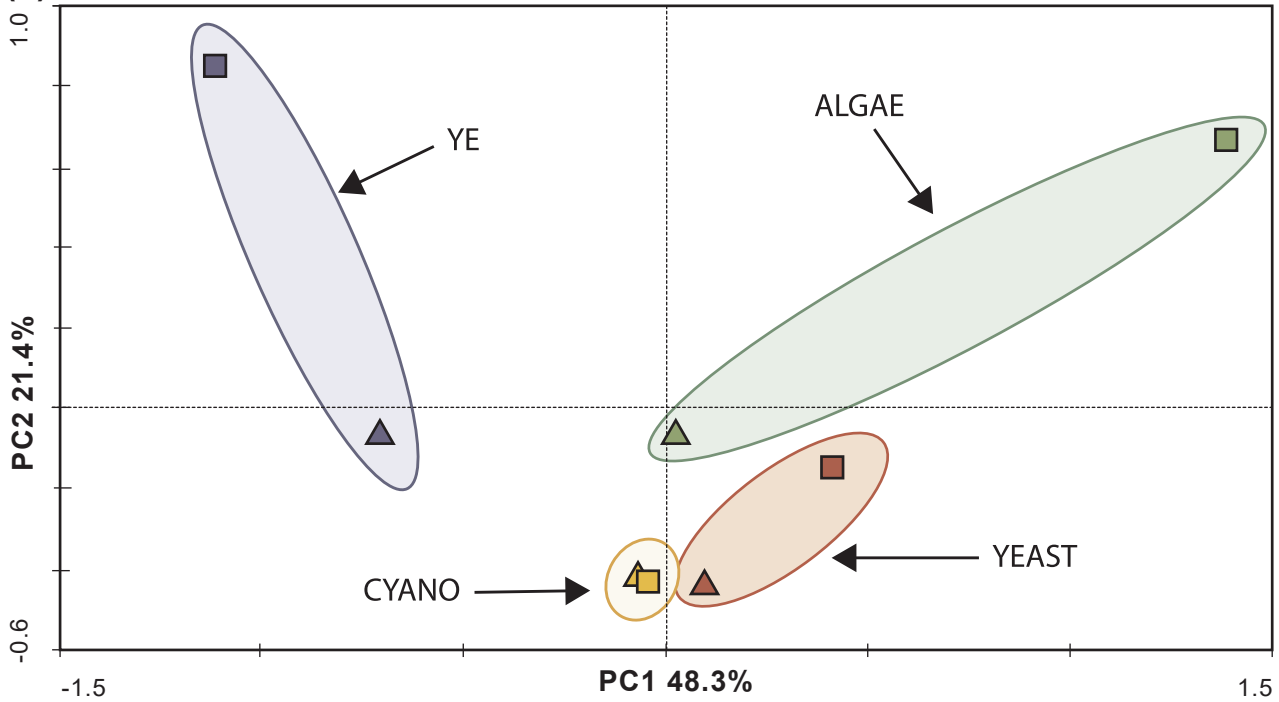

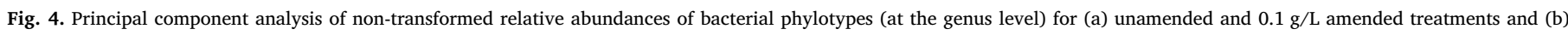
$0.5 \mathrm{~g} / \mathrm{L}$ amended treatments on day 111.

treatments, whereas the observed bacterial community differences for the $0.5 \mathrm{~g} / \mathrm{L}$ amendment treatments appeared to be driven more by amendment type. These results coincide with the observed carbon input-to-output ratios for the $0.5 \mathrm{~g} / \mathrm{L}$ treatments and indicate that too much amendment can affect the microbial community and shift the activity away from a coal-dependent system. All these observations together suggest that the lower amendment concentration provides a better return on investment and maintains coal-dependent conversions. The optimal type and amount of amendment for the most effective enhancement of coal-to methane conversion should be further investigated especially in the context of cost optimization and reducing microbial community shifts away from productive populations.

\section{Conclusions}

The research presented here shows (1) the importance of coal as a substrate in biogenic CBM production, as demonstrated in previous studies; (2) that algae, cyanobacteria, yeast and yeast extract amendments similarly increase rates of biogenic coal-to-methane conversion; (3) that increasing amendment concentrations increase the amount of methane formed but not proportionally to the amendment amount added; and (4) that microbial community composition appears to be dependent on the presence or absence of coal at low amendment concentrations but more dependent on amendment type at higher amendment concentrations. The results presented here also provide 
evidence for the utility of photosynthetically produced biomass (algae and cyanobacteria) for increasing MeCBM production and lay a foundation for further investigation and scale-up of the microbially-enhanced coalbed methane production technology in the field.

\section{Acknowledgments}

The authors would like to acknowledge the U.S. Geological Survey Energy Resources Program which provided access to the field site where the samples were collected. The authors would also like to thank Hannah Schweitzer, Heidi Smith, and Chiachi Hwang for their assistance in microbial community analysis and Joseph Parchen and Jill Story for their graphical expertise. Funding for this project was provided by the Department of Energy (DE-FE0024068). Partial financial support was provided by the Montana Research and Economic Development Initiative Contract \# 51040-MUSRI2015-05 and NSF CHE-1230632.

Disclaimer: Any use of trade, firm, or product names is for descriptive purposes only and does not imply endorsement by the U.S. Government.

\section{Appendix A. Supplementary data}

Supplementary data associated with this article can be found, in the online version, at http://dx.doi.org/10.1016/j.fuel.2017.09.074.

\section{References}

[1] McGlade C, Speirs J, Sorrell S. Unconventional gas - a review of regional and global resource estimates. Energy 2013;55:571-84. http://dx.doi.org/10.1016/j.energy. 2013.01.048.

[2] U.S. Energy Information Administration. Natural Gas - U.S. Energy Information Administration (EIA). Nat Gas 2017. http://www.eia.gov/naturalgas/ [accessed January 13, 2017].

[3] Strąpoć D, Mastalerz M, Dawson K, Macalady J, Callaghan AV, Wawrik B, et al. Biogeochemistry of microbial coal-bed methane. Annu Rev Earth Planet Sci 2011;39:617-56. http://dx.doi.org/10.1146/annurev-earth-040610-133343.

[4] Golding SD, Boreham CJ, Esterle JS. Stable isotope geochemistry of coal bed and shale gas and related production waters: a review. Int J Coal Geol 2013;120:24-40. http://dx.doi.org/10.1016/j.coal.2013.09.001.

[5] Flores RM, Rice CA, Stricker GD, Warden A, Ellis MS. Methanogenic pathways of coal-bed gas in the Powder River Basin, United States: the geologic factor. Int J Coal Geol 2008;76:52-75. http://dx.doi.org/10.1016/j.coal.2008.02.005.

[6] Colosimo F, Thomas R, Lloyd JR, Taylor KG, Boothman C, Smith AD, et al. Biogenic methane in shale gas and coal bed methane: a review of current knowledge and gaps. Int J Coal Geol 2016;165:106-20. http://dx.doi.org/10.1016/j.coal.2016.08. 011.

[7] Schink B. Syntrophic associations in methanogenic degradation. In: Overmann PDJ, editor. Mol. basis symbiosis Berlin Heidelberg: Springer; 2005. p. 1-19. http://dx. doi.org/10.1007/3-540-28221-1_1.

[8] Ritter D, Vinson D, Barnhart E, Akob DM, Fields MW, Cunningham AB, et al. Enhanced microbial coalbed methane generation: a review of research, commercial activity, and remaining challenges. Int J Coal Geol 2015;146:28-41. http://dx.doi. org $/ 10.1016 / \mathrm{j}$.coal.2015.04.013.

[9] Meredith E, Wheaton J, Kuzara S. Coalbed_methane basics: ten years of lessons from the Powder River Basin. Montana: Montana Bureau of Mines and Geology; 2012.

[10] Gallagher LK, Glossner AW, Landkamer LL, Figueroa LA, Mandernack KW, Munakata-Marr J. The effect of coal oxidation on methane production and microbial community structure in Powder River Basin coal. Int J Coal Geol 2013;115:71-8. http://dx.doi.org/10.1016/j.coal.2013.03.005.

[11] Jones EJP, Harris SH, Barnhart EP, Orem WH, Clark AC, Corum MD, et al. The effect of coal bed dewatering and partial oxidation on biogenic methane potential. Int $\mathrm{J}$ Coal Geol 2013;115:54-63. http://dx.doi.org/10.1016/j.coal.2013.03.011.

[12] Huang Z, Urynowicz MA, Colberg PJS. Stimulation of biogenic methane generation in coal samples following chemical treatment with potassium permanganate. Fuel 2013;111:813-9. http://dx.doi.org/10.1016/j.fuel.2013.03.079.

[13] Green MS, Flanegan KC, Gilcrease PC. Characterization of a methanogenic consortium enriched from a coalbed methane well in the Powder River Basin, U.S.A. Int J Coal Geol 2008;76:34-45. http://dx.doi.org/10.1016/j.coal.2008.05.001.

[14] Ulrich G, Bower S. Active methanogenesis and acetate utilization in Powder River Basin coals, United States. Int J Coal Geol 2008;76:25-33. http://dx.doi.org/10. 1016/j.coal.2008.03.006.

[15] Barnhart EP, De León KB, Ramsay BD, Cunningham AB, Fields MW. Investigation of coal-associated bacterial and archaeal populations from a diffusive microbial sampler (DMS). Int J Coal Geol 2013;115:64-70. http://dx.doi.org/10.1016/j.coal. 2013.03.006.

[16] Harris SH, Smith RL, Barker CE. Microbial and chemical factors influencing methane production in laboratory incubations of low-rank subsurface coals. Int $\mathrm{J}$ Coal Geol 2008;76:46-51. http://dx.doi.org/10.1016/j.coal.2008.05.019.

[17] Jones EJP, Voytek MA, Corum MD, Orem WH. Stimulation of methane generation from nonproductive coal by addition of nutrients or a microbial consortium. Appl Environ Microbiol 2010;76:7013-22. http://dx.doi.org/10.1128/AEM.00728-10.

[18] Hoehler TM, Jørgensen BB. Microbial life under extreme energy limitation. Nat Rev Microbiol 2013;11:83-94. http://dx.doi.org/10.1038/nrmicro2939.

[19] Gilcrease PC, Shurr GW. Making microbial methane work: the potential for new biogenic gas. World Oil 2007:1-48.

[20] Rathi R, Priya A, Vohra M, Lavania M, Lal B, Sarma PM. Development of a microbial process for methane generation from bituminous coal at thermophilic conditions. Int J Coal Geol 2015;147:25-34. http://dx.doi.org/10.1016/j.coal.2015.06.004.

[21] Barnhart EP, Davis KJ, Varonka M, Orem W, Cunningham AB, Ramsay BD, et al. Enhanced coal-dependent methanogenesis coupled with algal biofuels: potential water recycle and carbon capture. Int J Coal Geol 2017;171:69-75. http://dx.doi. org/10.1016/j.coal.2017.01.001.

[22] Barnhart EP, Weeks EP, Jones EJP, Ritter DJ, McIntosh JC, Clark AC, et al. Hydrogeochemistry and coal-associated bacterial populations from a methanogenic coal bed. Int J Coal Geol 2016;162:14-26. http://dx.doi.org/10.1016/j.coal.2016. 05.001.

[23] Nichols HW, Bold HC. Trichosarcina polymorpha Gen. et Sp. Nov. J Phycol 1965;1:34-8. http://dx.doi.org/10.1111/j.1529-8817.1965.tb04552.x.

[24] Gardner RD, Cooksey KE, Mus F, Macur R, Moll K, Eustance E, et al. Use of sodium bicarbonate to stimulate triacylglycerol accumulation in the chlorophyte Scenedesmus sp. and the diatom Phaeodactylum tricornutum. J Appl Phycol 2012;24:1311-20. http://dx.doi.org/10.1007/s10811-011-9782-0.

[25] Barsanti L, Gualtieri P. Algae: anatomy, biochemistry, and biotechnology. New York: CRC Taylor \& Francis; 2006.

[26] Saghbini M, Hoekstra D, Gautsch J. Media formulations for various two-hybrid systems. Two-hybrid syst. Methods protoc. vol. 177. Humana Press Inc.; 2003. p. $15-40$.

[27] Kalra YP. Handbook of reference methods for plant analysis. CRC Press; 1998.

[28] Takahashi S, Tomita J, Nishioka K, Hisada T, Nishijima M. Development of a prokaryotic universal primer for simultaneous analysis of bacteria and archaea using next-generation sequencing. PLoS One 2014;9:e105592. http://dx.doi.org/10. 1371/journal.pone.0105592.

[29] Kozich JJ, Westcott SL, Baxter NT, Highlander SK, Schloss PD. Development of a dual-index sequencing strategy and curation pipeline for analyzing amplicon sequence data on the MiSeq Illumina sequencing platform. Appl Environ Microbiol 2013;79:5112-20. http://dx.doi.org/10.1128/AEM.01043-13.

[30] Kamagata Y, Kawasaki H, Oyaizu H, Nakamura K, Mikami E, Endo G, et al. Characterization of three thermophilic strains of Methanothrix ("Methanosaeta") thermophila sp. nov. and rejection of Methanothrix ("Methanosaeta") thermoacteophila. Int J Syst Bacteriol 1992;42:463-8.

[31] Patel GB, Sprott GD. Methanosaeta concilii gen. nov., sp. nov. ("Methanothrix con cilii") and Methanosaeta thermoacetophila nom. rev., comb. nov. Int J Syst Evol Microbiol 1990;40:79-82. http://dx.doi.org/10.1099/00207713-40-1-79.

[32] Parshina SN, Ermakova AV, Bomberg M, Detkova EN. Methanospirillum stamsii sp. nov., a psychrotolerant, hydrogenotrophic, methanogenic archaeon isolated from an anaerobic expanded granular sludge bed bioreactor operated at low temperature. Int J Syst Evol Microbiol 2014;64:180-6. http://dx.doi.org/10.1099/ijs.0. 056218-0.

[33] Rowe AR, Mansfeldt CB, Heavner GL, Richardson RE. Methanospirillum respiratory mRNA biomarkers correlate with hydrogenotrophic methanogenesis rate during growth and competition for hydrogen in an organochlorine-respiring mixed culture. Environ Sci Technol 2013;47:372-81. http://dx.doi.org/10.1021/es303061y.

[34] Bräuer SL, Cadillo-Quiroz H, Ward RJ, Yavitt JB, Zinder SH. Methanoregula boone gen. nov., sp. nov., an acidiphilic methanogen isolated from an acidic peat bog. Int $\mathrm{J}$ Syst Evol Microbiol 2011;61:45-52. http://dx.doi.org/10.1099/ijs.0.021782-0.

[35] Yashiro Y, Sakai S, Ehara M, Miyazaki M, Yamaguchi T, Imachi H. Methanoregula formicica sp. nov., a methane-producing archaeon isolated from methanogenic sludge. Int J Syst Evol Microbiol 2011;61:53-9. http://dx.doi.org/10.1099/ijs.0. 014811-0.

[36] Singh DN, Kumar A, Sarbhai MP, Tripathi AK. Cultivation-independent analysis of archaeal and bacterial communities of the formation water in an Indian coal bed to enhance biotransformation of coal into methane. Appl Microbiol Biotechnol 2012;93:1337-50. http://dx.doi.org/10.1007/s00253-011-3778-1.

[37] Wawrik B, Mendivelso M, Parisi VA, Suflita JM, Davidova IA, Marks CR, et al. Field and laboratory studies on the bioconversion of coal to methane in the San Juan Basin. FEMS Microbiol Ecol 2012;81:26-42. http://dx.doi.org/10.1111/j.15746941.2011.01272.x.

[38] Zhang J, Liang Y, Pandey R, Harpalani S. Characterizing microbial communities dedicated for conversion of coal to methane in situ and ex situ. Int J Coal Geol 2015;146:145-54. http://dx. doi.org/10.1016/j.coal.2015.05.001.

[39] Rice CA, Nuccio V. Water produced with coal-bed methane. U.S. Geological Survey Fact Sheet FS 156-00; 2000.

[40] Hodgskiss LH, Nagy J, Barnhart EP, Cunningham AB, Fields MW. Cultivation of a native alga for biomass and biofuel accumulation in coal bed methane production water. Algal Res 2016;19:63-8. http://dx.doi.org/10.1016/j.algal.2016.07.014. 